\title{
Relapsing polychondritis: commentary
}

\section{La policondrite ricorrente: revisione critica}

\author{
I. Herrera' ${ }^{1}$, A. Mannoni ${ }^{2}$, R.D. Altman ${ }^{1}$ \\ ${ }^{\prime}$ Department of Rheumatology and Immunology, University of Miami School of Medicine and the Geriatric Research, \\ Education and Clinical Center, Miami Veterans Affairs Medical Center, Miami, Florida, United States of America, \\ and ${ }^{2}$ Sezione di Reumatologia, Azienda Sanitaria di Firenze
}

\begin{abstract}
RIASSUNTO
Sebbene venga descritta raramente, la Policondrite Ricorrente $(P R)$ è probabilmente più frequente di quanto la letteratura suggerisca. È una malattia sistemica ad eziologia ignota caratterizzata da poussées infiammatorie ricorrenti delle strutture cartilaginee. I fenomeni immunitari dimostrati sia nel siero sia a livello tissutale nell'uomo e nell'animale e la risposta terapeutica agli immunosoppressori fanno ritenere che la malattia abbia una genesi autoimmune. Le strutture cartilaginee più colpite sono quelle auricolari, nasali e laringo-tracheo-bronchiali ed il coinvolgimento di quest'ultime e dell'apparato cardiovascolare rappresentano le complicanze più gravi ed a prognosi sfavorevole quoad vitam. La diagnosi si basa sui reperti clinici ed eventualmente sull'esame bioptico delle strutture coinvolte. La Tomografia Computerizzata e le prove di funzionalità respiratoria sono indagini utili nella valutazione dell'estensione dell'ostruzione dell'albero respiratorio. Data la rarità della patologia non esistono studi controllati su provvedimenti terapeutici, pertanto è difficile identificare la terapia più efficace. I corticosteroidi sono efficaci nel controllo delle poussées infiammatorie ma non è certo che siano in grado di controllare la progressione della malattia. Altri farmaci immunosoppressori sono stati utilizzati in forme di PR refrattarie.

La PR è probabilmente una malattia immunomediata. Dal momento che non esiste un consenso su criteri diagnostici e sulla terapia, la Policondrite Ricorrente continua a rimenere una sfida diagnostica e terapeutica.
\end{abstract}

Reumatismo, 2002; 54(4):301-306

$\mathrm{R}^{2}$ elapsing Polychondritis (RP) is a multisystem disease of unknown etiology characterized by episodic inflammation of cartilage and potentially progressive degeneration of cartilaginous tissue, such as auricular, nasal and laryngotracheobronchial cartilage. However, many other proteoglycan-rich structures may be involved, such as inner ear, eyes, blood vessels, heart and kidneys (14). RP was first described by Jacksh-Wartenhorst in 1923, who named it "polychondropathia" (5). Pearson et al. (6) introduced the term "relapsing polychondritis" in 1960.

\section{IS THE PATHOGENESIS UNDERSTOOD?}

Although the pathogenesis is unknown, RP is thought to have several immunologic mechanisms:

\footnotetext{
Corrispondenza a:

Dr Roy D. Altman and Dr Ivonne Herrera

Miami VA Medical Center, 1201 N. W. 16 St.

Miami, Fl 33125, USA.

E-mail: raltman@med.miami.edu
}

1) Antibodies to collagen type II are present in up to two thirds of all cases during the acute phase of the disease (7). However, these antibodies are widely distributed throughout all cartilages and are not unique to RP. They have also been described in $20 \%$ of patients with rheumatoid arthritis (8-10).

2) The tissue-specific nature of RP suggests that an autoantigen found only in the affected cartilage may be the trigger of this disease. Matrilin- 1 is a cartilage matrix protein found uniquely in the auricular, nasal, tracheal and costochondral cartilage. A humoral and a cellular immune response toward matrilin- 1 was demonstrated in a patient with RP (11). Hansson et al. (12) established an animal model for matrilin 1-induced RP.

3) Immuno-fluorescence studies of affected cartilage have also shown granular deposits of immunoglobulin (Ig) G, IgA, IgM and complement (C) 3 suggesting the presence of immune complexes (13).

4) Some authors have found evidence of cell-mediated immune responses to various cartilage components (14). 
5) An increase in HLA-DR4 antigen was detected in patients with RP, as in rheumatoid arthritis, although no subtype predominated (15).

An additional indirect evidence of RP being immunologically mediated is the ability to control many of the manifestations of disease by immunosuppressive agents, such as corticosteroids.

\section{HOW ADEQUATE IS THE CLINICAL DESCRIPTION?}

The initial clinical description performed by JakschWartenhorst (5) highlights the most common clinical features. He reported a 32-yr-old brewery worker in Prague who initially had joint swelling and pain associated with fever. Later the brewery worker developed burning pains in both external ears, which slowly became swollen. In 3 months the swelling receded and the tissue shrunk, leaving deformity of both pinna. The brewery worker then developed a painless collapse of the cartilage of his nose, resulting in a saddle nose deformity. By that time, there was nearly complete stenosis of both external auditory canals and there was decreased auditory acuity, even with the canals held open. A constant mild dizziness and tinnitus were present.

Since the initial description, more than 700 cases have been reported adding clinical features (16-19). Laryngotracheobronchial complications are severe manifestations of the disease and predict a poor prognosis. Respiratory tract involvement occurs initially in $14 \%$ and eventually involves $56 \%$ of cases $(1,2)$. Airway obstruction can be diffuse or local involving several mechanisms:

1) In an active stage of RP, there may be acute swelling of the walls of the airway, narrowing the airway.

2) After the acute swelling, the walls of the airway may become contracted from the resultant postinflammation fibrous tissue.

3) Destruction of the laryngeal, tracheal, and/or bronchial cartilage by the inflammation results in a dynamic collapse of the airway. Airway tissue changes resulting from the above is a main cause of death. Infections of the airway or postobstructive pneumonia is the other main cause of death.

Cardiovascular involvement occurs in $24 \%$ to $52 \%$ of patients and usually appears late in the course of RP; a mean of six years after the onset $(1,2,20)$. The most common abnormalities induced by RP are aortic regurgitation and aortic aneurysm. Arte- rial and venous thrombosis occur with or without vasculitis and may be associated with an antiphospholipid antibody (21).

Ocular symptoms are eventually present in $50 \%$ of patients; almost any part of the eye can be involved with inflammation.

Renal disease, most commonly mild mesangeal proliferation, is rare and may occur independent of an associated connective tissue disease (e. g., SLE) (22). Although frequent, dermatologic manifestations are nonspecific and could not be defined as characteristic of RP (23).

Neurologic disease, such as cranial neuropathies, is particularly uncommon (24).

\section{IS THE DIAGNOSIS ALWAYS CLEAR?}

The diagnosis of RP can easily be overlooked due to its low incidence and atypical initial symptoms. Moreover many conditions can mimic the clinical presentation such as infection, allergic reactions, trauma, tumors, systemic vasculitis or other connective tissue diseases $(4,19)$. There is often a delay in diagnosis with the initial presentations misdiagnosed as infection. Because of the cyclic nature of RP, there seems to be a response to the antibiotic. Because of recurrence, several antibiotics are often administered before diagnosis is suspected.

Trentham et al. (3) reported a mean delay from the first visit to a doctor until diagnosis was 2.9 years. The delay was longer than one year for $68 \%$ of patients and one third of patients attended five or more physicians before RP was diagnosed.

Table I - Diagnostic Criteria for Relapsing Polychondritis by McAdam et al. (1)

1. Recurrent chondritis of both auricles

2. Chondritis of nasal cartilages

3. Chondritis of the respiratory tract involving laryngeal and/or tracheal cartilages

4. Nonerosive inflammatory polyarthritis

5. Inflammation of ocular structures including conjunctivitis, keratitis, scleritis/episcleritis and uveitis

6. Choclear or vestibular damage manifest by neurosensory hearing loss, tinnitus and vertigo

7. Cartilage biopsy confirmation of a compatible histologic picture 
Diagnostic criteria were first described by McAdam et al. in 1976 (1) (Tab. I): Biopsy of involved auricular or other cartilage can confirm the diagnosis, but biopsy may not be necessary in the presence of a typical clinical presentation. Three of six criteria need to be present.

More liberal diagnostic criteria were introduced by Damiani and Levine in 1979, requiring only one of three criteria (25) (Tab. II). These two sets of criteria seem to complement each other and several authors propose using both sets of diagnostic criteria with the diagnosis confirmed if the patient meets either set.

A third set of diagnostic criteria were introduced by Michet et al. in 1986 (2) (Table III). Only one of two criteria are needed and the criteria overlap with the prior proposed criteria sets. There has not been a consistent use of one set of diagnostic criteria over another.

There are no specific or reliable markers for diagnosis of RP. In addition there are no reliable markers to determine disease activity. An elevated erythrocyte sedimentation rate is the most frequent laboratory abnormality. Antinuclear antibodies (ANA) are uncommon. Indeed, Piette et al. (26) reported that a significant titer of ANA in a patient with RP strongly suggests the presence of an associated disorder, such as systemic lupus erythematosus, mixed connective tissue disease or Sjogren's syndrome. Antineutrophil cytoplasmic anti-

Table II - Diagnostic Criteria for Relapsing Polychondritis by Damiani and Levine (25)

1. At least three of McAdam's criteria, then no histological confirmation needed.

2. One or more of McAdam's signs with histological confirmation.

3. Chondritis in two or more separate anatomical locations with response to steroids and/or dapsone.

Table III - Diagnostic Criteria for Relapsing Polychondritis by Michet et al. (2)

1. Inflammatory episodes involving at least two of three sites: auricular, nasal or laryngotracheal cartilage

2. One of those sites and two other manifestations, including ocular inflammation (conjunctivitis, keratitis, episcleritis, uveitis), hearing loss, vestibular dysfunction or seronegative inflammatory arthritis bodies (ANCA) with specificity for both myeloperoxidase and proteinase 3 are present in up to $25 \%$ of patients with RP; only $10 \%$ of this group had evidence of vasculitis $(27,28)$. Anti-type II collagen antibodies do not correlate with disease activity or severity (3).

Because of the potential severity of the respiratory manifestations, all patients with RP should undergo evaluation for laryngotracheal involvement, regardless of the presence of the airway symptoms (29). Imaging studies, such as computed tomography (CT) of the laryngotracheobronchial tree may show thickening of the soft tissues lining the larynx, trachea and bronchi, collapse of the lumen and calcification of the airway wall $(30,31)$. Magnetic resonance imaging (MRI) is superior to CT in distinguishing between fibrosis, inflammation and edema (32).

Pulmonary function tests can assess the nature of the airway obstruction (33-35). Spirometry typically shows an obstructive ventilatory pattern. Flow volume loops demonstrate:

1) whether the obstruction is fixed or dynamic;

2 ) whether the location of the obstruction is intraor extrathoracic.

Fiberoptic bronchoscopy provides less information than $\mathrm{CT}$ scan and carries a risk for exacerbating airway inflammation.

Echocardiography, cardiac catheterization and angiography should be done in patients with prominent symptoms and signs of cardiovascular involvement, such as aortic regurgitation and/or aortic aneurysm to establish severity of illness and to have a baseline for comparison in followup.

\section{IS PRESENT DAY TREATMENT ADEQUATE?}

No single medicinal or surgical treatment is uniformly effective in relieving symptoms or preventing disease progression. Since RP is uncommon, controlled therapeutic trials have not been feasible. Corticosteroids are the mainstay of treatment to date, they decrease the frequency, duration and severity of flares; however, they do not prevent disease progression in more severely affected individuals (1). Corticosteroids or nonsteroidal antiinflammatory drugs (NSAIDs) are used to manage mild disease such as mild auricular, nasal and costochondral chondritis, or synovitis. It is uncertain whether corticosteroids prevent recurrent attacks. Anecdotal reports of the use of dapsone (100 $\mathrm{mg}$ /day), or colchicine ( $0.6 \mathrm{mg}$ twice daily) have 
been published as an alternatives to corticosteroids for mild nasal or auricular chondritis (36-41). In 3 patients colchicine aborted acute attacks of chondritis in 2 to 4 days $(36,38)$. Auricular chondritis refractory to conventional therapy and dermatologic manifestations have been treated successfully with methotrexate $(15-20 \mathrm{mg} /$ day $)(42,43)$, Trentham et al. (3) reported methotrexate as the most efficacious non-corticosteroid agent, although it has been ineffective in other reports (44-46). For moderate to severe disease, such as laryngotracheobronchial disease, eye involvement, inner ear inflammation, systemic vasculitis, aortitis, valvular heart disease or glomerulonephritis more aggressive therapy is indicated.

High dose intravenous corticosteroids appear to be effective in treatment of life threatening acute airway obstruction (47), but do not appear of benefit when there is loss of tracheal cartilaginous support (1). Apparently, subclinical inflammation in the aortic wall and in the heart valves continues despite corticosteroids therapy alone or in combination with cytotoxic agents $(20,48)$. At this time, the risk benefit ratio for long-term use of corticosteroids in RP is not well established. Cyclophosphamide $(2-3 \mathrm{mg} / \mathrm{kg} /$ day orally or $1 \mathrm{gr}$ intravenous pulse) $(47,49,50)$, azathioprine $(2-3 \mathrm{mg} / \mathrm{kg} / \mathrm{day})$ $(46,49,51)$, cyclosporine $(4-15 \mathrm{mg} / \mathrm{kg} /$ day) $(46$, $52,53)$ and penicillamine (54) have been employed with varying success. These agents have never been compared; hence, there is insufficient evidence on superiority of one agent over the other.

Other therapies reported in refractory cases are plasmapheresis, anti-CD4 monoclonal antibodies and autologous stem-cell transplantation (55-57). We could find no published information regarding $\mathrm{RP}$ and treatment with anti tumor necrosis factor (TNF) agents such as infliximab or etanercept.

Nebulized racemic adrenaline decreases airway inflammation during acute flares (58). Nasal continuous positive airway pressure has been used as a "pneumatic" splint for the affected airway and prevents tracheobronchial collapse (59). Tracheostomy is indicated for glottic and subglottic edema $(1,30,60)$. The placement of stents may be used to prevent collapse or dilate stenotic areas in the presence of tracheobronchial disease (61). Complications of intraluminal silastic stents include hemorrhage, sudden asphyxia from stent displacement, aspiration pneumonia if the stent extends through the vocal cords, mucosal ulcerations or scarring from chronic used and retention of secretions caused by impaired coughing (62). More re- cently, self-expandable metallic stents (SEMSs) offer some advantages over silastic stents. SEMSs are completely assimilated into the endothelium and incorporated into the tracheobronchial wall in 4 to 6 weeks, preventing migration, encrustation, infections or accumulation of secretions. It also allows intubation through a tracheal stent if necessary, and it can be place easily by fiberoptic bronchoscopy in an outpatient setting $(31,61,63,64)$. The ideal type of stent and the optimal timing of its placement remain to be established although it has been suggested that stenting should be considered early in the course of tracheobronchial disease $(63,64)$. External airway splinting to adjacent tissues such as the aorta has been attempted to prevent tracheal collapse with inconsistent results. Experience in laryngotracheal reconstruction is limited and not encouraging.

Patients with acute inflammatory heart block may benefit from systemic corticosteroids. However, a permanent pacemaker may be requiered. Although severe cardiac valvular disease or a large vessel aneurysm warrants surgical intervention, long term results are disappointing (65). High rate of paraprosthetic dehiscence has been reported within a few months of surgery. Because of silent aortitis may persist despite treatment with corticosteroids, patients who undergo aortic valve replacement should also have prophylactic composite graft replacement of the ascending aorta with coronary artery reimplantation $(39,44)$. Isolated aortic valve replacement increases the risk of aortic root aneurysm and secondary prosthesis dehiscence (66).

\section{REFERENCES}

1. McAdam LP, O’Hanlan MA, Bluestone R, Pearson CM. Relapsing polychondritis. Prospective study of 23 patients and a review of the literature. Medicine (Baltimore) 1976; 55: 193-215.

2. Michet CJ Jr, McKenna CH, Luthra HS, O'Fallon WM, Relapsing polychondritis. Survival and predictive role of early disease manifestations. Ann Intern Med 1986; 104: 74-8.

3. Trentham DE, Le CH. Relapsing polychondritis. Ann Intern Med 1998; 129: 114-22.

4. Zeuner M, Straub RH, Rauh G, Albert ED, Scholmerich J, Lang B. Relapsing polychondritis: Clinical and immunogenetic analysis of 62 patients. J Rheumatol 1997; 24: 96-101.

5. Jacksh-Wartenhorst F. Polychondropatia. Wien Arch Inn Med 1923; 6: 93-100.

6. Pearson MC, Kline MH, Newcomer DV: Relapsing polycchondritis. N Engl J Med 1960; 263: 51-8. 
7. Foidart JM, Abe S, Martin G, Zizic TM, Barnett EV, Lawley TJ, et al. Antibodies to type II collagen in relapsing polychondritis. N Engl J Med 1978; 299: 1203-7.

8. Terato K, Shimozuru Y, Katayama K, Takemitsu Y, Yamashita I, Miyatsu M et al. Specificity of antibodies to type II collagen in rheumatoid arthritis. Arthritis Rheum 1990; 33: 1493-500.

9. Cook AD, Rowley MJ, Mackay IR, Gough A, Emery P. Antibodies to type II collagen in early rheumatoid arthritis: correlation with disease progression. Arthritis Rheum 1996; 39: 1720-7.

10. Clague RB, Morgan K, Reynolds, I, Williams HJ. The prevalence of serum IgG antibodies to type II collagen in American patients with rheumatoid arthritis. Br J Rheumtol 1994; 33: 336-8.

11. Buckner JH, Wu JJ, Reife RA, Terato K, Eyre DR. Autoreactivity against matrilin-1 in a patient with relapsing polychondritis. Arthritis Rheum 2000; 43: 939-43.

12. Hansson AS, Heinegard D, Holmdahl R. A new animal model for relapsing polychondritis, induced by cartilage matrix protein (matrilin-1). J Clin Inves 1999; 104: 589-98.

13. Dolan DL, Lemmon GB Jr, Teitelbaum SL. Relapsing polychondritis. Analytical literature review and studies on pathogenesis. Am J Med. 1966; 41: 285-86.

14. Yang CL, Brinckmann J, Rui HF, Vehring KH, Lehmann H, Kekow J, et al. Autoantibodies to cartilage collagens in relapsing polychondritis. Arch Dermatol Res 1993; 285: 245-9.

15. Lang B, Rothenfusser A, Lanchbury JS, Rauh G, Breedveld FC, Urlacher A, et al. Susceptibility to relapsing polychondritis is associated with HLA-DR4. Arthritis Rheum 1993; 36: 660-4.

16. O'Hanlan MA, McAdam LP, Bluestone R, Pearson $\mathrm{CM}$. The arthropathy of relapsing polychondritis. Arthritis Rheum 1976; 19: 191-4.

17. Balsa A, Espinosa A, Cuesta M, MacLeod TI, GijonBanos J, Maddison PJ. Joint symptoms in relapsing polychondritis. Clin Experim Rheum 1995; 13: 425-30.

18. Luthra HS. Relapsing polychondritis. In Klippel JH, Dieppe PA, eds: Textbook of Rheumatology $2^{\text {nd }}$ ed.London, UK: Mosby; 1998: 5.27.1-5.27.4.

19. Arkin CR, Masi AT. Relapsing polychondritis: review of current status and case report. Semin Arthritis Rheum 1975; 5: 41-62.

20. Rosso Ad, Petix NR, Pratesi M, Bini A. Cardiovascular involvement in relapsing polychondritis. Sem Arthritis Rheum 1997; 26: 840-4.

21. Quere I, Biron C, Dubois A. Lupus anticoagulant and thrombosis in relapsing polychondritis. J Rheum 1996; 23: 946.

22. Daniel L, Granel B, Dussol B, Weiller PJ, Pellissier JF. Recurrent glomerulonephritis in relapsing polychondritis. Nephron 2001; 87: 190-1.

23. Frances C, El Rassi R, Laporte JL, Rybojad M, Papo T, Piette JC. Dermatologic manifestations of relapsing polychondritis. Medicine 2001; 80: 173-9.

24. Hanslik T, Wechsler B, Piette JC, Vidailhet M, Robin PM, Godeau P. Central nervous system involvement in relapsing polychondritis. Clin Experim Rheum 1994; 12: $539-41$
25. Damiani JM, Levine HL. Relapsing polychondritis. Laryngoscope 1979; 89: 929-46.

26. Piette JC, El Rassi R, Amoura Z. Antinuclear antibodies in relapsing polychondritis. Ann Rheum Dis 1999; 58: 656-7.

27. Masterson R, Sheerin N, Abbs I, Goldsmith D. Late allograft loss due to recurrence of p-ANCA-associated systemic vasculitis in a patient with relapsing polychondritis. Nephrol Dial Transplant 2001; 16: 1705-7.

28. Priori R, Conti F, Pittoni V, Valesini G. Relapsing polychondritis: a syndrome rather than a distinct clinical entity? Clin Experim Rheum 1997;15: 334-5.

29. Sridharan ST. Relapsing polychondritis. In Hoffman GS, Weyand CM eds: Textbook of Inflammatory diseases of blood vessels $1^{\text {st }}$ ed. New York:Marcel Dekker;2001: p.675-693.

30. Spraggs P, Tostevin P, Howard D. Management of Laryngotracheobronchial sequelae and complications of relapsing polychondritis. Laryngoscope 1997; 107: 936-41.

31. Sarodia BD, Dasgupta A, Mehta AC. Management of airway manifestations of relapsing polychondritis. Chest 1999; 116: 1669-75.

32. Heman-Ackah YD, Remley KB, Goding GS. A new role for magnetic resonance imaging in the diagnosis of laryngeal relapsing polychondritis. Head Neck 1999; 21: 484-9.

33. Mohsenifar Z, Tashkin DP, Carson SA, Bellamy PE. Pulmonary function in patients with relapsing polychondritis. Chest 1982; 81: 711-7.

34. Krell WS, Staats BA, Hyatt RE. Pulmonary function in relapsing polychondritis. Am Rev Respir Dis 1986; 133: $1120-3$.

35. Tillie-leblond I, Wallaaert B, Leblond D, Salez F, Perez $\mathrm{T}$, Remy-Jardin $\mathrm{M}$ et al. Respiratory involvement in relapsing polychondritis. Clinical, functional, endoscopic and radiographic evaluations. Medicine 1998; 77 : 168-76.

36. Askari AD. Colchicine for treatment of relapsing polychondritis. J Am Acad Dermatol 1984; 10: 507-10.

37. Weismann K, Graham RM. Systemic disease and the skin. In: Champion, RH, Burton JL, Ebling FJG, editors. Rook/Wilkinson/Ebling Textbook of Dermatology. $5^{\text {th }}$ ed. London: Blackwell Scientific Publications; 1992.p.2436-7 and 1799-1801.

38. Mark KA, Franks AG Jr. Colchicine and indometacin for the treatment of relapsing polychondritis J Am Acad Dermatol 2002; 46: S22-4.

39. Martin J, Roenigk HH Jr, Lynch W, Tingwald FR. Relapsing polychondritis with dapsone. Arch Dermatol 1976; 112: 1272-4.

40. Barranco VP, Minor DB, Solomon H. Treatment of relapsing polychondritis with dapsone. Arch Dermatol 1976; 112: 1286-8.

41. Delgado J, Gomez-Cerezo J, Siguenza M, Barbado FJ, Dupond JL, Vazquez JL. Relapsing polychondritis and erythema elevatum diutinum: an unusual association refractory to dapsone. J Rheumatol 2001; 28: 634-5.

42. Park J, Gowin KM, Schumacher HR Jr. Steroid sparing effect of methotrexate in relapsing polychondritis. 
J Rheumatol 1996; 23: 937-8.

43. Imai H, Motegi M, Mizuki N, Ohtani H, Komatsuda A, Hamai K et al. Mouth and genital ulcers with inflamed cartilage (MAGIC syndrome): a case report and literature review. Am J Med Sci 1997; 314: 330-2.

44. Miler SB, Donlan CJ, Roth SB. Hodgkin's disease presenting as relapsing polychondritis. Arthritis Rheum 1974; 17: 598-602.

45. Choy EH, Chikanza IC, Kingsley GH, Panayi GS. Chimaeric anti-CD4 monoclonal antibody for relapsing polychondritis. Lancet 1991; 338: 450.

46. Knipp s, Bier H, Horneff G, Specker C, Schuster A, Schroten $\mathrm{H}$, et al. Relapsing polychondritis in childhood - case report and short review. Rheumatol Int 2000; 19: 231-4.

47. Lipnick RN, Fink CW. Acute airway obstruction in relapsing polychondritis: treatment with pulse methylprednisolone. J Rheumatol 1991; 18: 98-9.

48. Buckley LM, Ades PA. Progressive aortic valve inflammation despite apparent remission of relapsing polychondritis. Arthritis Rheum 1992; 35: 812-4.

49. Hoan-Xuan T, Foster CS, Rice BA. Scleritis in relapsing polychondritis. Response to therapy. Ophtalmology 1990;97: 892-8.

50. Ruhlen JL, Huston KA, Wood WD. Relapsing polychondritis with glomerulonephritis. Improvement with prednisone and cyclophosphamide. JAMA 1981; 245: $847-8$

51. Yamazaki K, Suga T, Hirata K. Large vessel arteritis in relapsing polychondritis J Laryngol Otol 2001; 115: 836-8.

52. Ormerod AD, Clark LJ. Relapsing polychondritis- treatment with cyclosporing A. Br J Dermatol 1992; 127: 300-1.

53. Priori R, Paroli MP, Luan FL, Abdulaziz M, Pivetti P, Valesini G. Cyclosporin A in the treatment of relapsing polychondritis with severe recurrent eye involvement. Br J Rheum 1992; 32: 352.

54. Crockford MP, Kerr IH. Relapsing polychondritis. Clin Radiol 1988; 39: 386-90.
55. Rosen O, Thiel A, Massenkeil G, Hiepe F, Haupl T, Radtke $\mathrm{H}$ et al. Autologous stem-cell transplantation in refractory autoimmune diseases after in vivo immunoablation and ex vivo depletion of mononuclear cells. Arthritis Research 2000; 2: 327-36.

56. Botey A, Navasa M, del Omlmo A, Montoliu J, Ferrer O, Cardesa A, Darnell A, Revert L. Relapsing polychondritis with segmental necrotizing glomerulonephritis. American J Nephrology 1984; 4: 375-8.

57. Lubbe van der PA, Miltenburg AM, Breedveld FC. Anti-CD4 monoclonal antibody for relapsing polychondritis. Lancet 1991; 337: 1349.

58. Gaffney RJ, Harrison M, Path FRC, Blaney AW. Nebulized racemic ephedrine in the treatment of acute exacerbations of laryngeal relapsing polychondritis. J Laryngol Otol 1992; 106: 63-4.

59. Adliff M, Ngato D, Keshavjee S, Brenaman S, Granton JT. Treatment of diffuse tracheomalacia secondary to relapsing polychondritis with continuous positive airway pressure. Chest 1997; 112: 1701-4.

60. Dunne JA, Sabanathan S. Use of metallic stents in relapsing polychondritis. Chest 1994; 105: 864-7.

61. Dunne JA, Sabanathan S. Use of metallic stents in relapsing polychondritis. Chest. 1994; 105: 864-7.

62. Eng J, Sebanathan S. Airway complications in relapsing polychondritis. Ann Throrac Surg 1991; 51: 686-92.

63. Faul JL, Kee ST, Rizk NW. Endobronchial stenting for severe airway obstruction in relapsing polychondritis. Chest 1999; 116: 825-7.

64. Shah R, Sabanathan S, Mearns AJ, Featherstone H. Self-expanding tracheobronchial stents in the management of major airway problems. J Cardiovasc Surg 1995;36: 343-8.

65. Vandecker W, Panidis IP. Relapsing polychondritis and cardiac valvular involvement. Ann Intern Med 1988;109: 340-431.

66. Lang-Lazdunski L, Hvass U, Paillole C, Pansard Y, Langlois J. Cardiac valve replacement in relapsing polychondritis: A review. J Heart Valve Dis 1995; 4: 227-235. 